\title{
Critical Thinking as a Dimension of Constructivist Learning in Social Studies Education: A Study of Teachers' Attitudes in Secondary Education
}

\author{
Ali Emad Muhammad \\ Department of Social Work \\ Salahaddin University-Erbil, Iraq
}

Received: March 13, 2020

Accepted: April 22, 2020

Published: May 1, 2020

doi:10.5296/jse.v10i2.16763

URL: https://doi.org/10.5296/jse.v10i2.16763

\begin{abstract}
This study examined social studies teachers' attitudes towards critical thinking as a dimension of constructive learning. The purpose of this study was indeed to develop a better understanding of the use of instructional approaches by experienced teachers to enhance critical thinking skills and improve student learning of social studies. The study was conducted in the city of Erbil in Iraqi Kurdistan with 20 experienced social studies teachers in 8 public secondary schools. Qualitative approach was preferred for this study. The interview with each of the 20 teachers was conducted individually and their social studies classes are observed separately. The results of this study revealed that teachers have little knowledge and understanding of instructional strategies that foster critical thinking. The teachers believed that students can benefit from using self-learning, self-assessment, involving in peer learning, meaningful and reasonable response process and express curiosity through questioning how and why. This study also explored some obstacles when teachers practice instructional strategies that enhance critical thinking in learning social studies.
\end{abstract}

Keywords: Critical thinking; Constructivist learning; Social studies; Secondary education; Teacher's attitudes 


\section{Introduction}

Social studies entail domains apart from social history, as revealed in the National Council of Social Studies (Herczog, 2010). This stands for human understanding, laws and a different way of life in human society, social studies reflect those fields of subject matter called human life, science and mathematics. The goal of social studies education at classrooms environment is to diversify student understanding of reality for youth in a multi-cultural and inclusive community to make rationally and critically based decisions on the well-being and good citizens (Veltri, 2014).

Social studies are helping secondary learners gain a greater understanding of future decision-making (Hinde \& Perry, 2007). There are explanations that students learn to study social studies to develop a better understanding of the world and use critical thinking to find solutions and to be responsive to circumstances that are difficult (Khan \& Inamullah, 2011). Their basic beliefs on the world have a significant impact on their progression to be productive members of society of the 21 st century (Little, Feng, VanTassel-Baska, Rogers, \& Avery, 2007). Nevertheless, few studies investigate how secondary teachers of social studies utilize teaching methods to improve the critical thinking of students in secondary classrooms.

\subsection{Background of the Study}

Jere Brophy (1990) states that critical thinking contributes to social studies in a manner that allows students to critically examine and resolve problems related to social studies. Debate and constructive discussions are promoted to enhance the critical thinking skills of students who are willing to use secondary teachers to correlate social studies with the real situations of life (America, 2009; Dudduan, Nirat, \& Sumalee, 2015). Dudduan et al., (2015) recommended that secondary teachers design exercises that address how, why and what questions when demonstrations and meaningful discussions are used. Other approaches, for example, visual organizers can motivate students to think social studies affectively (Dudduan et al., 2015).

Students can be more effective and productive as they learn in a meaningful way social studies (Kaptan \& Timurlenk, 2012). Socratic education approach is a technique that could stimulate critical thinking. This practice encourages students to concentrate not on responses, but on questions students have to analyze their thoughts and ideas through studying (Lai, 2011). Students become well prepared to respond to the difficulties of critical thinking in secondary education with a good understanding of social studies (Marks, 2000). Nonetheless, there are few studies that represent or investigate how teachers incorporate critical thinking to enhance approaches for teaching essential social studies in secondary social studies (Kwan \& Wong, 2015). The objective of this research was indeed to develop a better understanding of the use of instructional approaches by experienced secondary school teachers to enhance critical thinking skills and improve student learning of social studies.

Social studies must be learned to assist students to comprehend the modern age and to practice critical thought to address issues and to be responsible for circumstances of complexity (Jere Brophy, 1990). There is limited evidence in this area how experienced 
teachers in secondary school social studies may foster critical thinking skills through curriculum approaches and improve students' social studies depth of understanding.

\subsection{A theoretical background}

Constructivist philosophy highlights the central position of students in active learning that enable them to improve thinking skills (Taber, 2011). The cognitive development approach of Piaget relies on using context to comprehend the progress of individual mental structures and behaviors (Easley, 1978). Piaget maintains the concept that individuals conceptualize and understand the world and use this experience for understanding, transforming and assimilating their existing beliefs and attitudes. According to Easley (1978) Piaget assumed that people had changed their views, behaviors and processes, so that they could adjust through a deeper understanding of the reality. Therefore, knowledge creation is based on individual investigations and thinking processes and on collaboration with the environment (Gordon, 2009). Therefore, the cognitive development process states that individuals must ensure the balance of assimilation and accommodation in order to make effective understanding and to regenerate the existing problem (Je Brophy \& Jere Brophy, 2002). It can be argued from a social constructivist standpoint that although the Piaget research did not focus on the importance of social background and society, it proposed that social and cultural elements of learning and understanding necessity (Je Brophy \& Jere Brophy, 2002). For instance, Piaget's knowledge creation was in a specific social-cultural context with three study respondents and tools that indicate recognition of the social learning framework (Gordon, 2009). Teachers should therefore foster student-cantered approaches that involve the mental ability of students to be responsible for their learning. To create activities that would reinforce higher level thinking through certain practices in social studies, secondary teachers could therefore use constructivist theories.

A further constructivist from Vygotsky (1978) said that a diverse culture requires social environments that could improve mental intelligent development. Secondary school teachers can indeed educate diverse student groups through different social needs in social studies. Thus teacher provides the enthusiasm in students to be educated in a specific subject (Dewey, 1916, 2012), either in pairs or on an individual basis. Secondary schools should connect real social-life experiences with social studies to significantly improve students' critical thinking skills (Alazzi, 2008). Students develop and build understanding from what they have already experienced from the constructive philosophical perspective (Honebein, Duffy, \& Fishman, 1993). Students learn more with the things they have experienced in their actual lives or something that they can relate to. The conclusions from this research may present students with insights into the effective learning of social studies through strategies enhance critical thinking in secondary social studies.

\subsection{Statement of the Problem}

It is unidentified how secondary school teachers utilize teaching methods to facilitate the critical thinking of their students in social studies. Social studies in secondary schools are not acknowledged as a subject (Jones \& Thomas, 2006). There is insufficient evidence in the region about the use of learning approaches for secondary education by teachers that 
encourage thinking skills and strengthen student learning regarding social studies (Alazzi, 2008).

Secondary-school students at a crucial stage have a considerable impact on their growth into productive $21^{\text {st }}$ century citizens with respect to their essential worldview (Debabrata \& Cuenca, 2015). Additional research is necessary for identifying effective instructional approaches in the social study education at secondary level that can influence the students' critical thinking.

\subsection{Research Questions}

1. What are attitudes of social studies teachers towards instructional strategies that can enhance critical thinking skills of students?

2. What are challenges to social studies teachers when integrating approaches of critical thinking in social studies?

\section{Literature review}

The value of social studies in modern culture is a significant need for young people to understand and fully realize. Critical thinking induces students to rationalize their analytical skills at a higher level of secondary social studies (Hartshorne, Waring, \& Okraski, 2019). The purpose of education and learning is to empower students for a global society. Estanek \& Love (2003) explained how teaching will promote analytical thought by involving the whole individual and it is important that learner to be trained and qualified for the modern and globalized world that confronts everyone individually, economically and professionally. Regardless of whether inside or outside classes, the ultimate objective of a teacher at school is to foster students with the necessary skills in the 21 st century.

\subsection{Constructivist learning and social studies}

The theoretical and constructivist paradigm in conceptual progressive social studies was drawn from Dewey (1916), Piaget (1952), and Vygotsky (1978) theories. Constructivist learning has been the modern and progressive form in learning today and paves the way to prepare secondary students to develop their critical thinking in social studies.

Secondary social studies teachers should inspire students to become critical thinkers, as they appear in accordance with constructionist approaches of teaching. Therefore, students will construct an understanding of a certain subject not the teacher who provides information and answers (Waite-Stupiansky, 1995).

In comparison to individual students in the modern period, secondary students in social studies will construct their own inquiries and should pursue solutions and thus take up their own learning duties (Brooks \& Brooks, 1999). The students should think more critically and reason more explicitly by using a constructive paradigm of learning (Eulie, 1968). The law of the NCSS allows teachers to use an enormous number of educational exercises, practical work and collaborations to develop critical thought in social studies. The theory of a child's internalization of environmental and social initiatives, which involve the interaction with 
others in the learning environment, was defended by Moore \& Piaget (1971). That means, an individual learns through understanding and converts the information into an instrument for better insight. According to Vygotsky, (2019) the teacher and student cooperate together to maximize the cognitive level of critical thinking skills of the student once the student comprehends the idea of practice. Rosenfeld \& Rosenfeld (2006) confirms that the teachers are guide for students in a constructivist learning environment, instead of attempting to answer all the questions. In other terms, teachers are sources of motivations for students to be participated actively by connecting a particular subject with real life situations and engage in learning process.

The students in social studies should explicitly share their experience of a specific subject of constructivist thinking instead of what the teacher demonstrates (Demiral, 2018; Lindqvist, 2003). Therefore, the students may create a way to internalize the concrete idea that critical thinking creates for them (Moore \& Piaget, 1971). Studies of Dewey (2006); Piaget (1952); Vygotsky (1978) have contributed to new learning approaches backed by constructivist theory which includes student-oriented learning and authentic learning in social studies in order to foster critical thinking in social studies.

For genuine instructing, according to Dewey, there must be more real content, more tools, more instruments and more opportunities to perform before the gap can be addressed. And also where learners are involved in doing tasks, it is observed, with even comparatively passive approaches of teaching, that students' enquiries are interactive and frequent, and that possibilities for solutions are sophisticated, diversified and innovative (1916). Dewey stresses the significance of developing a real-life learning ambience. For social constructivist learning this is essential. For social constructivist learning, this is regarded to be crucial (Gordon, 2009; Taylor, 2009). Teachers who use social-constructivist instruction should be able to perceive the interaction with the real setting, to stimulate reflection and exercise the built concepts (Vygotsky, 1978).

Constructivist learning involves the design of collaborative and cooperative learning environments that enhance the reflection and recognition of personal beliefs (Karagiorgi \& Symeou, 2005). The social context requires social construction of knowledge, but not all social contexts enhance the building of knowledge, as seen by Karagiorgi \& Symeou (2005). Social context makes meaning when knowledge building allows individuals to incorporate their concepts, thoughts and hypotheses into genuine-world practices by collaborative learning activities (Vygotsky, 2019).

\subsection{Critical thinking and social studies}

Constructivist learning is intended to encourage thinking, critical reasoning, comprehension learning and utilizing, individual self-regulation and reflective thinking (Watts, Jofili, \& Bezerra, 1997).Critical thinking, according to Tapung, Maryani, \& Supriatna (2018) is a way of thinking explicitly and critically to guide one's thoughts and actions. One has to set criteria to evaluate and enhance one's analytical and reasoning ability and improve ability to think critically. Akinoglu \& Baykin (2015) identified that the critical thinking of the individual requires a greater level of analytical thinking in the context of purpose, encouragement, focus, 
and logical thinking. The creation of critical thinking skills includes the ability to evaluate, criticize and bring creative ideas to a reasonable result (Eulie, 1968). Because these themes contribute to social studies, high school students can grasp the details of the lesson in relation to real-life, realistic learning experiences. Hartshorne et al., (2019) claimed that critical thinking contributes to the capacity to analyze, identify and address complicated issues. Such competencies include an understanding of social studies in the context of comprehension, the study of uncertain data, complex tools and the interaction between outcomes and everyday life. The primary goal of social studies is to teach students to think analytically and to produce thinkers, who make themselves better to be able to resolve issues, make decisions and act at a greater level within the society (Karabulut, 2012).

\subsection{Main mission of social studies and critical thinking}

Social studies in the previous decade were determined as the study of historical experience, geography and culture and government and politics in a multicultural society, this is according to the National Council on Social Studies (NCSS). Throughout recent years, the definition of social studies has been expanded by the NCSS to involve with individuals and establish diverse cultures (Herczog, 2010). In addition to being more active in the community, the aim of social studies by way of the NCSS is to encourage learners in secondary schools by including a better psychological and social environment for learning (America, 2009). Furthermore, the goal and purpose of social studies is to educate students in a global society and make right decisions to become functioning members of society (Little et al., 2007). Secondary students can incorporate the knowledge of class with the experience of real situations and with the ability to gain global knowledge and understanding (Khan \& Inamullah, 2011). The main focus or role of social studies, then, is to promote the creation of educated, conscientious and responsible individuals in their societies (Veltri, 2014). A significant element in social studies is students' critical thinking (Karabulut, 2012).

\subsection{Skills of critical thinking and social studies}

The aim of social studies is to encourage students to think analytically and to create thinkers into a greater level in the society for major issue-solving and choice-making (Karabulut, 2012). NCSS provides several separate publications, for students, in order to comply with the practical criteria of the social studies lesson plan, to develop critical thought skills in social studies: social education, social studies and young learner, and middle level training (Herczog, 2010).

The secondary teacher who instructs social studies is concerned with critical thinking. Debabrata \& Cuenca (2015) states that teachers seek to fulfill certain requirements that increase social study interests and learning. Teachers of social studies claim the resources supplied in the classroom environment can reflect the students' experience (Alazzi, 2008). This ensures that students are ultimately responsible for their learning and understanding in social studies through approaches centered on students. Learning tasks and strategies are needed along with various approaches which enhance students' understanding of social studies significantly(Bhakti, Ghiffari, \& Regita, 2018). As said Demiral (2018) one must gain the ability to analyze and check the details and knowledge gained in any context to strengthen 
critical thinking skills in all subjects. Critical thinking skills are constructed through various approaches of learning such as content of social studies (Alwadai, 2014; Bataineh \& Alazzi, 2009).

\section{Methodology}

A broader variety of studies have been carried out to research instructional approaches for the advancement of critical thinking abilities in the field of social studies in the promotion of critical thinking (Bhakti et al., 2018; Karabulut, 2012; Watts et al., 1997; Eulie, 1968). The method preferred was a qualitative approach that considered the viewpoints and perspectives of each participant as relevant points for examining teaching approaches that enhance critical thinking in social studies. A qualitative approach presents a greater perspective into the observed environment (Hillebrand \& Berg, 2000). In this study a basic qualitative approach used a limited sample size. The research was conducted to learn about the teacher's attitudes toward instructional approaches that foster the critical thinking skills of students in teaching social studies was intended to provide them with deeper understanding and perspectives than just utilizing measurements of percentages (Hillebrand \& Berg, 2000).

\subsection{Participants}

The research participants who were purposively recruited were 20 teachers in secondary public schools in the city of Erbil in Iraqi Kurdistan that teach social studies. Social studies teachers who had at least five years of experience and taught grades $10^{\text {th }}, 11^{\text {th }}$, and $12^{\text {th }}$ participated in this research. All teachers have been certified by the Kurdistan region of Iraq. The purposive sample approach is used for persons or groups who have a deep understanding of a relevant topic according to Tashakkori, Teddlie, \& Johnson (2015).

\subsection{Setting}

An interview was held between 35-40 minutes after school with the 20 participants separately. In the school's classroom, interviews were held to explore the learning approaches that have been utilized throughout classrooms to improve critical thinking in social studies. All school teachers took part in interviews on constructivist teaching and critical thinking conducted by training course of the ministry of education. Only 8 secondary schools have been preferred and selected in the city of Erbil. The schools are classified as A, B, C, D, E, F, G, and H. In every school social studies teachers are suggested by the headmaster. The head teacher recommended two social studies teachers in every school A, B, C, D, E, F, but in each school $\mathrm{G}$ and $\mathrm{H}$ four teachers were recommended. The interviews took place in a quiet area of the school where the teachers had the comfort to answer the questions they interviewed.

\section{Collecting data}

Interviews and observations were the two data sets used to examine research questions throughout the study.

\subsection{Interviews}

In the sense of simplicity, transparency as well as the potential to raise specific questions, 
interviews are the most effective method to qualitative data collectivity (Hillebrand \& Berg, 2000). The collected data that provide a specific number of participants or groups detailed information. Interviews were appropriate for this research due to secondary teachers' personal perspectives, instructional teaching in social studies, meaningful data, and useful background information. Interviews were performed and recorded independently in this basic qualitative interpretation. It ensured the participants privacy and confidentiality. There were 7 semi-structured questions for the interview. The questions of the interviewing were focused on research questions that added importance to the research. The questions of the interview were checked by the field study including three experts from the world of social studies. The specialists checked the details of the interview to insure that the main questions were particularly suitable for participants. The questions were modified based on the specialists' opinions and feedback. The interviewer used the interview questions to explore participant perspectives on how participants address a particular subject in social studies when providing remarks and feedback on interview questions (Tashakkori et al., 2015).

\subsection{Observations}

Observations are one of the traditional qualitative data collection processes. According to Tashakkori et al. (2015), recording details in a natural environment is allowed. Throughout the study the observations became the valid qualitative approach for assessing the classroom practices as changes to the sample can be identified at various phases (Hillebrand \& Berg, 2000).

The research was reviewed by three specialists before the study was conducted. Three specialists in the area of social studies were given approved field research methods. The purpose of the form was to allow experts to verify the reliability of the questions. The experts gave reviews on the importance of the questions after revising these questions. The questions were for school teachers who were teaching social studies. For several years, the experts have been studying and working on the subject.

The set of interview questions is modified as follows:

1. How do you explain the skills of critical thinking?

2. How do you think that students of social studies should gain critical thinking skills?

3. How are the students' critical thinking abilities in your social studies class environment?

4. What indications do you think of critical thinking skills in student behavior and attitude, classwork activities related to academic achievement?

5. What is your thought regarding on integrating critical thinking in social studies classroom with instructional approaches?

6. What are the reasons, if there are any that directly impact your opinion to use or not approaches for critical thinking in your classes?

7. When you use critical thinking skills in your teaching of social studies, what are challenges / barriers? 


\section{Ml Macrothink}

Journal of Studies in Education

ISSN 2162-6952

2020, Vol. 10, No. 2

Prior to performing the interviews, permission documents were received. The participants recognized that the study was completely voluntary and that though they had chosen to take part, though they decided to do so, they might withdraw at any point. The research was conducted confidentially by the participants. Each participant's classroom was observed by the researcher between 30-40 minutes. Several remarks comments and statements were made in the morning and afternoon schools. The process of interview and observation started from the first week of January of 2020 and ended the last week of February of 2020.

Interviews with participant teachers were conducted after the participants scheduled time. Teachers were interviewed individually and the interview on mobile phone was recorded. 8 males and 12 females took part in the study. The interviews were completed in the classroom with the consent of the teachers. It was 35-40 minutes each interview. After the interviews were recorded and documented, the interviews were transcribed with a specific perspective on the phenomena for clarity and analysis. The researcher wrote the questions and translated them into Kurdish. The teachers of the school shared the responses in Kurdish. The Kurdish researcher translated the responses of the teachers individually from Kurdish into English in order to ensure an accurate translation process.

Regarding the observation, particularly for the validity of the interview evidence, class observations were used. A guideline was prepared to concentrate on teaching and classroom activity. Approaches used to cultivate critical thinking in social studies were employed by students. Additional techniques were observed in which the students performed a task on their own through little guidance. The attitudes and perspectives of teachers are identified as following:

1. Teachers engaging with activities used in specific small groups.

2. Enable those students who struggle to grasp the material provided to be support by peer students.

3. How does the teacher lead the students to the subject before the class is begun in order to continue the critical thinking learning process?

4. How does the instructor concentrate on the subject when a disruption occurs?

5. When summarizing the lesson, how does' teacher criticizes the students' verbal or writing skills?

6. What kind of measurement has been used to evaluate student performance?

Teachers were classified in the order they were questioned through the use of the labels from T1 to T20. The descriptions of the 20 participants are mentioned in Table 1. 
Table 1. Demographics of participants interviewed

\begin{tabular}{|l|l|l|}
\hline & Teacher participants & Frequencies \\
\hline Gender & Male & 8 \\
& Female & 12 \\
\hline Age & $30-35$ & 6 \\
& $36-40$ & 9 \\
& $41-55$ & 5 \\
\hline Levels degrees & Bachelors & 20 \\
& Master & - \\
\hline Years of experience & $5-10$ & 8 \\
& $11-15$ & 12 \\
\hline
\end{tabular}

\section{Data analysis}

Two research questions, 7 interview questions and classroom observations addressed the process of data collection in this study. Every research question corresponds to the questions of the interview. Research Question 1 comprises four relevant interview questions and observation. Three linked interview questions and observation are also presented in Research Question 2.

The participants' statements were transcribed by interviews and data processing. Once the transcripts were created, codes and formulas for the different interviews took place. The outcomes of the participants' interpretations were primarily attitudes, experiences and practice. The coding of terms started to appear with the common patterns of the terms. Table 2 shows the themes constructed by the interview responses and observation. 
Table 2. Research question 1 involves emergence of major themes and patterns from the interview and observation responses

\begin{tabular}{|c|c|}
\hline Research question 1 & Emerged themes \\
\hline $\begin{array}{l}\text { What are attitudes of social studies } \\
\text { teachers towards instructional strategies } \\
\text { that can enhance critical thinking skills of } \\
\text { students? }\end{array}$ & $\begin{array}{l}\text { Abilities to think critically } \\
\text { - } \text { Thinking differently from a new } \\
\text { perspective } \\
\text { - Construct and critically assess } \\
\text { - Skills of creation of new } \\
\text { knowledge } \\
\text { Strategic Thinking Methods } \\
\text { - Reasonable and meaningful } \\
\text { Methods for self-learning } \\
\text { - Concerned with self-assessment } \\
\text { - Involving of students in peer } \\
\text { - learning } \\
\text { Expressing curiosity through } \\
\text { asking questions }\end{array}$ \\
\hline
\end{tabular}

\subsection{Abilities to think critically}

Critical thinking is a skill to regulate one's thoughts and reactions using various approaches to obtain the intended outcomes (Paul \& Elder, 2012). Learners can indeed practice ideas in different and specific contexts through critical thinking skills (Herczog, 2010). The below are the abilities that teachers claimed were indicators of critical thinking.

\subsubsection{Thinking differently from a new perspective}

Most participants described critical thinking as an individual who can clarify and think differently. Besides learners thinking creatively, the mechanism through which students acquire understanding is critical thinking. Secondary school teachers employed guiding questions to enable students to think different manner. Teachers think that schooling is a not a sequential form anymore. Students gain skills from their teachers or textbooks. T5 and T7 claimed that the teaching of social studies will contribute to the modern environment in which students experience such that they have a better understanding of the subject. Teachers realized that learning is not a simple process any more. Students gain experience and knowledge from their teachers or teaching materials. T3, T11 and T18 articulated that the social sciences teaching should be aimed at the actual environment in which students experience so that they can get a better understanding of the topic. T-3 stated that students clearly understand something they are confident engaging in different contexts. The teacher will show students various methods of learning. Students are therefore developing their own learning strategies. 


\subsubsection{Reasonable and meaningful responses process}

This is to the responses on particular questions pertaining to an examined topic is the students post. The students will address the query by utilizing the details of the text and by linking it with a real life experience. Students are often encouraged to cite what the writer said regarding the book. T2 gave an explanation of how her class utilized a meaningful response technique. First of all, the students were provided with video clips relating to the subject of the day from the internet. For around 5-7 minutes the students watched this film. The teacher answered questions about the film during the recording.

Through guidance of the teacher the student addressed the questions orally. The participant subsequently produced another example close to the machine film. This time, the students used to give a response by typing their comments in paragraph format on their papers. This was considered productive reaction by the participants.

"Secondary students are actually learning more than before" T2 said. In providing positive responses, students were motivated to give solid evidence of the responses to questions. The students then could not know of the responses. The students understand well, through providing positive responses

\subsubsection{Methods for self-learning}

T2, T13 and T18 indicated that many students have the potential to learn better through specific techniques. Once they clearly understand better, they can use logical reasoning to develop and implement their specific work. When a set of questions are addressed adequately, they moved on to a next class discussion, which is a higher level of thinking on different subjects in social studies. T8 clarified that students must have critical thinking ability to justify their answers. If students can clarify what they have to do to come up with a reasonable answer, then they have displayed logical thought in the context of self-learning strategies. T14 and T11 reflected that students would learn better of what they should anticipate from their teaching by breaking the lessons down into groups. However, the self-technique cannot be established by all the students.

\subsubsection{Concerned with self-assessment}

Most of the participants utilized self-evaluation techniques during the classroom observations. The self-assessment consisted of the preparation of the teacher and student. The student was deeply involved in the curriculum and developed responsibility of the lesson. When learners believed they were a part of the class, self-assessment was effective because of the participation of learners (Tofade, Elsner, \& Haines, 2013). Students even assessed themselves, whether they understood the content of the curriculum. The students have been given the proper and materials to be assessed. This approach has raised the curiosity of students and inspired them to practice better (Kostons, van Gog, \& Paas, 2012).

\subsubsection{Involving of students in peer learning}

Students may interact with others in some classes. The teacher must make plan for this collaborative learning process to succeed. According to Kostons et al. (2012) collaboration 
with peers will be ideal for students at secondary school in an environment that focuses on student learning. The students had the ability to connect and exchange thoughts regarding the current lesson. The students' roles and duties were chosen and assigned. The main purpose of such lesson with peers was specifically for the students to assign duties of each pair. When a member of that group can't perform its role, this was the group's responsibility to undertake. T3, T7 and T9 clarified that students appeared to better grasp one another than even the teacher. Working together helps with students who are reluctant to clarify their thoughts. Students may exchange concepts and likely create different views in order to understand a particular concept.

\subsubsection{Expressing curiosity through asking questions}

Many students grasp the idea while others do not as a teacher gives a lesson to social studies class. For learn, all students need to ask the questions why, how and when almost everything occurs. Most of the teachers emphasized that much of the primary critical thinking skills of social studies included giving clarification to how, why, and when questions. T9 and T15 claimed that the students' behaviors, attitudes and questioning would challenge and influence other students' learning curiosity in the classroom by giving attention.

Table 3 provides the arrangement of research questions 2, observation and interview questions, and combined with developed themes after transcripts were created, labeling and patterns occurred.

Table 3. Research question 2 involves emergence of major themes and patterns from the interview and observation responses

\begin{tabular}{|l|l|}
\hline Research question 2 & Emerged themes \\
\hline $\begin{array}{l}\text { What are challenges to social studies teachers } \\
\text { when integrating approaches of critical } \\
\text { thinking in social studies? }\end{array}$ & $\begin{array}{l}\text { Lack of motivation and interest of } \\
\text { students }\end{array}$ \\
& $\begin{array}{l}\text { Student's refusal to understand the } \\
\text { importance of social studies }\end{array}$ \\
& - Apparent lack of essential \\
& instructional resources \\
& $\begin{array}{l}\text { Absence of time and necessity for } \\
\text { preparation or readiness }\end{array}$ \\
\hline
\end{tabular}

\subsubsection{Lack of motivation and interest of students}

Participants found out that students are challenging to critically comment on the subject of Social Studies. Participants will seek to find efficient methods of increasing the students' curiosity. Another participant believed many students are not properly competent to be subjected to critical thinking. "The students ' experience contributes significantly to the change in social studies"T12, T17, and T19 said. Unless students are not prepared to critically analyze, they do not respond well in critical thought practice. "Once they become very skilled, students perform rather well in in critical thinking practices." T5 confirmed. Many other participants assured that students do better with various tasks while the students are advanced in educational success. 
Many participants assume that students are not particularly inspired in social studies to use critical reasoning techniques since the social study results do not depend on standardized assessments. They do not however want to understand exactly how social studies in our community are essential. T10 mentioned that by involving the students in the lessons, the teacher should maintain the enthusiasm of the students active and constructive. T6 and T13 noted that logical thought exercises are hard as students are unable to understand and want their task easier. Students want the teacher to respond every question to them. If students cannot seem to find the response, they get disappointed and they decide to stop practicing. Also, students do not prefer to get challenged and be frustrated by critical thought learning. Moreover, students appreciate easier truthful tasks and classwork. In addition to this, students are particularly worried regarding issues of interpretation that involve simple logical thinking. Students are often comforted with simple questions that mostly memorized answers are needed. In other words teachers enable students to easily acquire real facts or knowledge by rote learning and this instructional approach prevents students' potential from critical thinking.

\subsubsection{Student's refusal to understand the importance of social studies}

Most students could not grasp that why social studies needed to be learned. Social studies must be meaningful to everyday situations of students. T1, T13, T15 and T19 clarified that in social studies, the challenges teachers encounter involve attempting to improve students' behavior and students think social studies in their community are not important, and they are get bored. Students believe that the only subjects which matter are languages and mathematics. There is also a bad motivation for the class when they attend to a social studies lesson. T8 said that this barrier would prevent students to be enthusiastic in social studies class.

\subsubsection{Apparent lack of essential instructional resources}

Another consideration is that it will be inadequate key resources to study in social studies. When materials are provided to reinforce the lesson taught, students might indeed think about a specific matter. Many classrooms lack sufficient resources to carry out the learning activity or tasks. Teachers need to use enough tools to fulfill the expectations of students' long life learning. As critical thinking is necessary in social studies, certain tools and resources are derived from skilled professional learning. T7 and T 18 said the absence of teacher materials was a barrier to the usage of social studies of critical thinking tasks. When a new concept is introduced in a class, teachers ought to explain to the students in order to truly understand it deeper. When there are no resources, the idea of the lesson would be difficult for students to comprehend deeper. However, T8 clarified the importance of fostering critical thinking in education programs.T8 also added that there are normally several materials on the program. The materials typically provide teachers with teaching techniques that improve critical thinking mental capabilities.

\subsubsection{Absence of time and necessity for preparation}

Many participants believed that teaching social studies is a challenging experience for 
secondary teachers. As said T4, time is a crucial part in classroom learning. T9 stated that teachers typically wanted their students to finalize their classwork or tasks during the lesson. While students learn in class, they have almost no opportunities to participate in analytical thought. Most teachers found it is necessary that students have time to think before answering questions as they consider waiting time is an effective method in motivating students to reflect and to express opinions.

Students are not educated and trained in school because the subject fields of previous class are inadequately related to social studies. If students have to find a solution to a question, they will prefer a solution from Google rather than using thinking skills to find a response. Students are searching for low skilled work. And T14, T16 and T20 noted that it is challenging for both average and lower-average students to have detailed responses and they seem to mostly choose to get good and fast responses.

Almost all teachers thought that students have high priority for completing the national examination, as it entitles them to admission to top-ranking of state universities. The students' primary interest is to get a good degree rather than to truly grasp the contents of social studies.

\section{Discussion of results}

The findings for both of the two research questions addressed consisted of attitudes of social studies teachers were questioned, observed and interpreted. The results are presented.

\subsection{Results for first research question}

This research confirms that it is not a simple duty for teachers to convey critical thought while teaching social studies. The findings indicate that the experience of teachers greatly affect their acceptance of critical thinking and the usage of a range of strategies to enhance critical thinking ability in secondary schools. As confirmed by Akinoglu \& Baykin (2015) teachers do not fully recognize the value of developing student learning. It is consistent with other studies which found the experience of teachers in enhancing the critical thinking skills of secondary students (Bataineh \& Alazzi, 2009).

The research revealed that teachers use teacher-centered approaches that do not include sufficient critical thinking in the curriculum. It is highlighted by Paul \& Elder (2012) the teachers' experience that positively or negatively affects the development of the critical thinking skills of learners as they either boost or impair thought skills of students. The improvement of students' critical thinking skills is essential in this form of learning activity (Hartshorne et al., 2019). This research indicates that critical thinking is a crucial part of teaching social studies. Nonetheless, because of a lack of instructional experience, the teachers did not think that they were ready to educate critical thought to students and other techniques including "why" and "how" were suggested to make the students learn how to formulate a solution.

This study found that the majority of participants have little knowledge or understanding in using instructional strategies to reinforce critical thinking. They have shared their own 
opinions on the importance of cultivating and encouraging critical thought techniques among students. T4 said, for example, critical thinking was not valued much as it helps students to protest against state laws to ruin the society. Bhakti et al. (2018) backed these results limit teachers' instructional skills by offering students with clear and critical thinking and providing them inadequate resources for learning regardless of whether they correspond to the subject matter or not.

This study found that students can enhance thinking abilities by participating throughout engaging students with peers, self-learning, self-evaluation and self-selecting tasks strategies as the evidence of the critical thinking skills. According to Kostons et al. (2012) a collaborative effort with peers in an atmosphere that reflects on learning and understanding is particularly appropriate for secondary students. Vygotsky (1978) assumed that students gain skills in social interaction inside the cultural context. The results of this research are based on Dewey's research (2006), which encourages secondary students to develop their own approaches of learning and understanding.

\subsection{Results for second research question}

This study found that lack of time and readiness is confirmed to be a barrier when using critical thinking abilities incorporated to students' constructive learning. This finding is consistent with Alazzi (2008) and Alwadai (2014) research show that students may think critically with their own mental ability, but enhancing the ability of critical reasoning requires time, strategies and motives guided by teachers. According to Alwadai (2014) time is a significant obstacle in developing skills in critical thinking in large classrooms. They also found that teachers strive to provide students with knowledge in the specific field but experience time challenges with lack of useful learning tools to teach students critical thought. Paul \& Elder (2012) suggested that critical thinking should be included in all teaching materials, so all teachers will be ready to integrate critical thinking skill into teaching social studies.

This research reveals that due to lack of students' motivation and interests, students are not involved in learning social studies through critical thinking advanced strategies in a classroom environment. This finding is in line with Kwan \& Wong (2015) emphasized that motivating students to practice thinking skills in learning context such as conclusions drawn, taking decisions, and solving problems will enable them to think creatively and to make them more productive.

\section{Conclusion}

In examining the insights emerging from the research for secondary social studies teachers in the city of Erbil, a number of themes are carried out to clarify the obstacles and lack of critical thinking approaches in secondary schools. In the context of social studies in secondary education, educational approaches must be developed. This essential qualitative research provides instructional approaches that can encourage students to think critically and reveal challenges to teaching social studies by using approaches of critical thinking. This was strengthened by teachers who find critical thinking skills as meaningless while students 
preparing for national examinations. When some teachers stated in their interviews, students appear to value nothing not associated with their national test. Secondary social studies teachers are typically not unfamiliar with critical thinking definitions, strategies, and instructional methods. More studies are required to explore methods that indicate how to instruct the students about critical thinking. For secondary teachers it may be difficult to use instructional approaches to enhance and develop critical thinking in social studies. Through improving critical thinking ability, more students would be eager to engage in learning social studies. When students full engage, their interests and motivation can be developed to learn more about social studies, the society and the modern world.

\section{References}

Akinoglu, O., \& Baykin, Y. (2015). Raising critical thinkers: Critical thinking skills in secondary social studies curricula in Turkey. Anthropologist, 20(3), 616-624. https://doi.org/10.1080/09720073.2015.11891765

Alazzi, K. F. (2008). Teachers' Perceptions of Critical Thinking: A Study of Jordanian Secondary School Social Studies Teachers. The Social Studies, 99(6), 243-248. https://doi.org/10.3200/tsss.99.6.243-248

Alwadai, M. A. (2014). Islamic Teachers' Perceptions of Improving Critical Thinking Skills in Saudi Arabian Elementary Schools. Journal of Education and Learning. https://doi.org/10.5539/jel.v3n4p37

America, B. (2009). Powerful and Purposeful Teaching and Learning in Elementary School Social Studies. Social Studies and The Younger Learner.

Bataineh, O., \& Alazzi, K. (2009). Perceptions of Jordanian Secondary Schools Teachers towards Critical Thinking. International Education.

Bhakti, C. P., Ghiffari, M. A. N., \& Regita, S. M. (2018). Strategy of core curriculum to improving student's critical thinking skill. TERAPUTIK: Jurnal Bimbingan Dan Konseling, l(3), 176. https://doi.org/10.26539/1374

Brooks, J. J. G., \& Brooks, M. G. (1999). In Search of Understanding: The Case for Constructivist Classrooms. Association for Supervision and Curriculum Development. https://doi.org/10.1007/s13398-014-0173-7.2

Brophy, Je, \& Jere Brophy, D. (2002). Social constructivist teaching: Affordances and constraints. Vasa, i(9), 43-79. https://doi.org/10.1016/S1479-3687(02)80012-8

Brophy, Jere. (1990). Teaching Social Studies for Understanding and Higher-Order Applications. The Elementary School Journal. https://doi.org/10.1086/461623

Debabrata, A. R., \& Cuenca, A. (2015). Rethinking social studies teacher education in the twenty-first century. In Rethinking Social Studies Teacher Education in the Twenty-First Century. https://doi.org/10.1007/978-3-319-22939-3

Demiral, U. (2018). Examination of Critical Thinking Skills of Preservice Science Teachers: 
A Perspective of Social Constructivist Theory. Journal of Education and Learning, 7(4), 179. https://doi.org/10.5539/jel.v7n4p179

Dewey, J. (1916). The democratic conception of education. Democracy and Education: An Introduction to the Philosophy of Education.

Dewey, J. (2006). How we think. In How we think. https://doi.org/10.1037/10903-000

Dewey, J. (2012). Education and Democracy in the World of Today (1938). Schools. https://doi.org/10.1086/665026

Dudduan, C., Nirat, \& Sumalee, C. (2015). Development of learning management model based on constructivist theory and reasoning strategies for enhancing the critical thinking of secondary students. Educational Research and Reviews, 10(16), 2324-2330. https://doi.org/10.5897/err2015.2193

Easley, J. A. (1978). Book Reviews: Jean Piaget, The Development of Thought: Equilibration of Cognitive Structures. (Translation by Arnold Rosin of Volume 33 of the Études d'Épistémologie Génétique) New York: The Viking Press, 1977. 213 pp., \$12.50 . Educational Researcher. https://doi.org/10.3102/0013189x007011018

Estanek, S., \& Love, P. (2003). Critical Thinking and Seamless Learning: A Post-Modern Approach. Inquiry: Critical Thinking Across the Disciplines. https://doi.org/10.5840/inquiryctnews2003/2004231/233

Eulie, J. (1968). Developing Critical Thinking and Understanding through the Social Studies. The Social Studies, 59(5), 216-221. https://doi.org/10.1080/00220973.1942.11018922

Gordon, M. (2009). The misuses and effective uses of constructivist teaching. Teachers and Teaching: Theory and Practice. https://doi.org/10.1080/13540600903357058

Hartshorne, R., Waring, S. M., \& Okraski, H. (2019). Developing Well-informed, Critically Thinking, and Active Citizens Through the Connection of Modeling \& Simulation and Social Studies Education. The Clearing House: A Journal of Educational Strategies, Issues and Ideas, 92(1-2), 48-52. https://doi.org/10.1080/00098655.2019.1571988

Herczog, M. (2010). Using the NCSS national curriculum standards for social studies: A framework for teaching, learning, and assessment to meet state social studies standards. Social Education.

Hillebrand, J. D., \& Berg, B. L. (2000). Qualitative Research Methods for the Social Sciences. Teaching Sociology. https://doi.org/10.2307/1319429

Hinde, E. R., \& Perry, N. (2007). Elementary teachers' application of Jean Piaget's theories of cognitive development during social studies curriculum debates in Arizona. Elementary School Journal. https://doi.org/10.1086/522386

Honebein, P. C., Duffy, T. M., \& Fishman, B. J. (1993). Constructivism and the Design of Learning Environments: Context and Authentic Activities for Learning. In Designing Environments for Constructive Learning. https://doi.org/10.1007/978-3-642-78069-1_5 
Jones, R. C., \& Thomas, T. G. (2006). Leave No Discipline Behind. The Reading Teacher. https://doi.org/10.1598/rt.60.1.6

Kaptan, K., \& Timurlenk, O. (2012). Challenges for Science Education. Procedia - Social and Behavioral Sciences. https://doi.org/10.1016/j.sbspro.2012.08.237

Karabulut, Ü. S. (2012). How to teach critical-thinking in social studies education: An examination of three NCSS journals. Egitim Arastirmalari - Eurasian Journal of Educational Research.

Karagiorgi, Y., \& Symeou, L. (2005). Translting Constructivism Into Learning Design: Potential and Limitations. Educational Technology \& Society.

Khan, W. B., \& Inamullah, H. M. (2011). A study of lower-order and higher-order questions at secondary level. Asian Social Science. https://doi.org/10.5539/ass.v7n9p149

Kostons, D., van Gog, T., \& Paas, F. (2012). Training self-assessment and task-selection skills: A cognitive approach to improving self-regulated learning. Learning and Instruction. https://doi.org/10.1016/j.learninstruc.2011.08.004

Kwan, Y. W., \& Wong, A. F. L. (2015). Effects of the constructivist learning environment on students' critical thinking ability: Cognitive and motivational variables as mediators. International Journal of Educational Research, 70, 68-79. https://doi.org/10.1016/j.ijer.2015.02.006

Lai, E. . (2011). Critical Thinking: A Literature Review. Transfusion. https://doi.org/10.1046/j.1537-2995.1995.35395184278.x

Lindqvist, G. (2003). Vygotsky's Theory of Creativity. Creativity Research Journal. https://doi.org/10.1207/s15326934crj152\&3_14

Little, C. A., Feng, A. X., VanTassel-Baska, J., Rogers, K. B., \& Avery, L. D. (2007). A study of curriculum effectiveness in social studies. Gifted Child Quarterly. https://doi.org/10.1177/0016986207302722

Marks, H. M. (2000). Student engagement in instructional activity: Patterns in the elementary, middle, and high school years. American Educational Research Journal. https://doi.org/10.3102/00028312037001153

Moore, G. T., \& Piaget, J. (1971). Science of Education and the Psychology of the Child. Journal of Architectural Education (1947-1974). https://doi.org/10.2307/1423801

Paul, R., \& Elder, L. \& F. for C. T. (2012). The miniature guide to critical thinking: Concepts and tools. 27th International Conference on Critical Thinking. https://doi.org/10.1002/pfi.4170340606

Piaget, J. (1952). When thinking begins. The Origins of Intelligence in Children. https://doi.org/10.1037/h0051916

Rosenfeld, M., \& Rosenfeld, S. (2006). Understanding teacher responses to constructivist 


\section{$\Lambda$ Macrothink}

Journal of Studies in Education

ISSN 2162-6952 2020, Vol. 10, No. 2

learning environments: Challenges and resolutions. Science Education. https://doi.org/10.1002/sce.20140

Taber, K. S. (2011). Constructivism as educational theory: Contingency in learning, and optimally guided instruction. In Educational Theory.

Tapung, M., Maryani, E., \& Supriatna, N. (2018). Improving students' critical thinking skills in controlling social problems through the development of the emancipatory learning model for junior high school social studies in manggarai. Journal of Social Studies Education Research, 9(3), 162-176. https://doi.org/10.17499/jsser.23826

Tashakkori, A., Teddlie, C., \& Johnson, B. (2015). Mixed Methods. In International Encyclopedia of the Social \& Behavioral Sciences: Second Edition. https://doi.org/10.1016/B978-0-08-097086-8.10550-1

Taylor, E. W. (2009). Mezirow, Jack, Edward W. Taylor, et al. Transformative Learning in Practice: Insights from Community, Workplace, and Higher Education. Journal of Teaching Writing.

Tofade, T., Elsner, J., \& Haines, S. T. (2013). Best practice strategies for effective use of questions as a teaching tool. American Journal of Pharmaceutical Education. https://doi.org/10.5688/ajpe777155

Veltri, B. T. (2014). Social studies teaching for learners who engage. In Media Rich Instruction: Connecting Curriculum to All Learners. https://doi.org/10.1007/978-3-319-00152-4_10

Vygotsky, L. S. (1978). Mind and Society: The Development of Higher Psychological Processes. In Harvard University Press. https://doi.org/(Original manuscripts [ca. 1930-1934])

VYGOTSKY, L. S. (2019). Interaction between Learning and Development. In Mind in Society. https://doi.org/10.2307/j.ctvjf9vz4.11

Waite-Stupiansky, S. (1995). The road to constructivist classrooms: In search of understanding: The case for constructivist classrooms. Educational Forum. https://doi.org/10.1080/00131729409336369

Watts, M., Jofili, Z., \& Bezerra, R. (1997). A case for critical constructivism and critical thinking in science education. Research in Science Education, 27(2), 309-322. https://doi.org/10.1007/BF02461323 